\title{
Gamma Radiated Wheat for Combating Devastating Blast Disease (Magnaporthe Oryzae Triticum) In Bangladesh
}

\author{
Md. Harun-Or-Rashid ${ }^{1}$, M. Bahadur Meah ${ }^{1}$, Md. Imtiaz Uddin², Sharif Ahmed ${ }^{3} \&$ Md. Abul Kashem² \\ ${ }^{1}$ Bangladesh Agricultural University, Mymensingh, Bangladesh \\ ${ }^{2}$ Bangladesh Institute of Nuclear Agriculture, Mymensingh, Bangladesh \\ ${ }^{3}$ International Rice Research Institute, Bangladesh office, Bangladesh \\ Correspondence: Md. Harun-Or-Rashid, Department of Plant Pathology, Bangladesh Agricultural University, \\ Mymensingh-2202, Bangladesh Tel: 880-177-435-5442. E-mail: harun.hmml@gmail.com
}

Received: October 24, 2019 Accepted: November 25, 2019 Online Published: December 3, 2019

\begin{abstract}
Wheat is a global food security crop, providing 20 percent of protein and calories consumed worldwide and up to 50 percent in developing countries. It is the second most important cereal next to rice in Bangladesh and playing an important role in attaining food security. But wheat is very susceptible to diseases that often place major biological constraints on production. In 2016, a new wheat disease called "blast" was identified by wheat scientists for the first time in Bangladesh. Wheat blast disease caused by Magnaporthe oryzae triticum is causing enormous yield loss worldwide. At present, control of blast disease is a great challenge due to frequently introduction of new races of the pathogen. The present investigation focused on screening M2 population of gamma radiated wheat where four doses of radiations viz. $150 \mathrm{~Gy}, 200 \mathrm{~Gy}, 250 \mathrm{~Gy}$, and $300 \mathrm{~Gy}$ were applied to the seeds of three wheat varieties viz. BARI Gom-25, BARI Gom-29 and BARI Gom-30 from a Cobalt 60 source (Gamma Chamber 5000). The irradiated seeds were sown in farmers' fields of a wheat blast disease-prone area Chandbil, Meherpur Sadar. All the doses of irradiation showed a significant effect on incidence and severity of wheat blast disease in all three varieties. Among the treatments $200 \mathrm{~Gy}$ and $250 \mathrm{~Gy}$ reduced the disease effectively. Molecular detection of Magnaporthe oryzae triticum was also done using specific primer. The size of the band ( $350 \mathrm{bp})$ confirms the infection of M2 families by Magnaporthe oryzae triticum. Development of wheat blast resistant variety through irradiation could be a potential substitute to replace the available chemical control methods and it is described as eco-friendly, sustainable and nonhazardous strategy to reduce wheat yield loss due to blast disease.
\end{abstract}

Keywords: gamma radiation, wheat blast, resistant cultivar, disease incidence, disease severity

\section{Introduction}

Wheat (Triticum aestivum L.), belongs to the family Poaceae, is one of the most important cereals in the world. Wheat forms the base of global food security, providing $20 \%$ of protein and calories of the majority of the population in developing countries (Singh et al., 2016). Almost 50\% of the total world production of grain crops is occupied by wheat (Banglapedia, 2014). Wheat is cultivated in the world over a large area and under varied climatic conditions ranging from sub-tropical to temperate (Singh et al., 2016). Wheat is the second most important cereal next to rice in Bangladesh and playing an important role in attaining food security.

Wheat in Bangladesh usually faces some abiotic (heat, salinity, drought, etc.) and biotic (disease, insect, weeds, etc.) stresses (Ahmed et al., 2019). Among the diseases, leaf rust, leaf blight, head blight, etc. are usually prevalent in this environment. However, in 2016, a new devastating wheat disease named wheat blast caused by Magnaporthe oryzae triticum was identified by wheat scientists for the first time in Bangladesh (FAO Report, 2016). Wheat blast suddenly appeared in Bangladesh in Kustia, Meherpur, Chuadanga, Jhenaidah, Jashore, Barishal, Bhola and some other districts in the South. The affected areas were approximate $\sim 20 \%$ of Bangladesh's total wheat producing area in 2015-16, presenting a significant threat to the country's aggregate wheat production (Meah et al., 2016).

The wheat blast was first reported in 1985 in Paraná, Brazil (Igarashi et al., 1986) and has since spread throughout many wheat-producing areas of Brazil and to the neighboring countries such as Bolivia and Paraguay (Goulart et al., 2007; Kohli et al., 2011). 
The pathogen of wheat blast disease has the potential to infect all the above-ground parts of wheat plant (Igarashi, 1991). The most significant symptom of wheat blast in the field is the premature bleaching of spikelets (Igarashi, 1991; Urashima, 2010). In severe cases, the entire head is damaged. If head infection occurs early grain production can be critically lost. Blackening of the rachis, lower nodes, shriveling of grains, low test weight has also been observed (Malaker et al., 2016).

Blast fungus is disseminated by air and seeds (Monsur et al., 2016). Seed transmission is considered to be a feature that is significant for its dispersal by humans (Kato, 1994). Besides, there are several strains of M. oryzae which tend to display a degree of host specificity and they have been divided into pathotypes based on their host preference (Cruz et al., 2016). Based on the molecular characteristics, the pathogen strain of wheat blast found in Bangladesh was similar to the strain of Brazil (Malaker et al., 2016).

The South American countries Brazil and Bolivia tried to develop resistant variety through conventional breeding. But the result is not mentionable. The alternative method of developing resistant variety is irradiation (Özge Çelik and Çimen Atak., 2017). Radiation usually causes large chromosomal aberration and chemical mutagens cause point mutations (Raina et al., 2016; Raina et al., 2017 and Khursheed et al., 2017). Mutation breeding is hugely successful. The wide use of mutation induction for crop improvement is documented in the IAEA (2017) mutant variety database. Over 3275 mutant varieties in more than 220 plant species have been officially released worldwide to date (FAO/IAEA, 2018).

The main mutagenic crops improved for disease resistance are rice, barley, maize, wheat, bean, green pea. Recently in 2017, Niab Kinnow mutant variety of Citrus reticulata has been developed from bud woods of local Kinnow irradiated at 20 Gy of gamma rays (IAEA Mutant variety database, 2017). This variety has shown moderate to high resistance to Citrus canker, scab, and wither-tip diseases as well as a low incidence to major insect pests (IAEA Mutant variety database, 2017).

Bangladesh Institute of Nuclear Agriculture (BINA) developed some resistant varieties of rice and other cereals (BINA, 2018). The rice varieties developed by BINA using irradiation are Binadhan-4, Binadhan-5, Binadhan-6, Binadhan-7, Binadhan-9, Binadhan-13, Binadhan-14, Binadhan-18 and Binadhan-19 ( BINA, 2018 and IAEA mutant variety database 2017). Binadhan-19 was developed from NERICA-10 through irradiation at 40 Gy of gamma rays (BINA, 2018).

It is reported that Bangladeshi wheat blast pathogen Magnaporthe oryzae triticum strains are more aggressive than those reported earlier (CIMMYT, 2017). The conventional methods of gene isolation and transfer have been tried for this strain. The approach irradiation of seeds to bring a small change in the genetic makeup has not been tried. In the proposed research program, the possibility of creating a mutant resistant to Magnaporthe oryzae triticum was found through seed radiation.

Radiation in wheat seeds has never before been given to obtain a mutant resistant against wheat blast pathogen Magnaporthe oryzae triticum. This could be an alternative approach to develop wheat variety resistant to Magnaporthe oryzae triticum.

\section{Materials and Methods}

Field experiments were carried out in Bangladesh Institute of Nuclear Agriculture (BINA) farm, Mymensingh and farmers' fields of Chandbil village at Meherpur Sadar during the 2017-2018 season. Laboratory works were accomplished in the Integrated Pest Management (IPM) Lab of Bangladesh Agricultural University (BAU) and Biotechnology Lab of Bangladesh Institute of Nuclear Agriculture (BINA). The field experiment was laid out in a completely randomized design with four doses of gamma ray application, i.e., 150, 200, 250 and $300 \mathrm{~Gy}$ on three latest developed wheat varieties such as BARI Gom-25, BARI Gom-29 and BARI Gom-30 with replicated thrice. The soil of the experimental plot was sandy loam with moderate fertility. Seeds of wheat varieties were irradiated using a cobalt source ray @ 150 Gy, 200 Gy, 250 Gy, and 300 Gy. Irradiated seeds were sown in line of 2.5 m long with a seed rate of $120 \mathrm{~kg} \mathrm{ha}^{-1}$. The non-irradiated seeds of each variety were sown as control.

The land was prepared following standard procedure of wheat cultivation. Fertilizers and manures were applied as per recommendation of BARI (Anonymous, 2012). After sowing the seeds in the plot, the upper portion of the plot soil was leveled manually. Continuous supervisions were done to protect the experimental plot from external hazards such as birds, fox, animals, etc. M1 ( $1^{\text {st }}$ year population of irradiated seeds) plants were grown in the field of BINA and M2 ( $2^{\text {nd }}$ year population of irradiated seeds) plants were grown at Chandbil, Meherpur. Both fields were irrigated two times and manual hand weeding once for weed control. No pesticides were applied. In both fields none of the M1 or M2 plants were inoculated. The plants were kept under continuous observation for the expression of wheat blast symptoms. Data on the parameters were recorded: days to symptom expression, disease 
incidence, and disease severity. The infected plant samples (spikes) were collected for the determination of Magnaporthe oryzae triticum through clinical and molecular assay using specific primer.

\subsection{Sample Collection}

Samples of spikes were collected from both M1 and M2 plants. Blast infected spikes were collected in brown paper bags, dried in room temperature and afterward the samples were stored at $4{ }^{\circ} \mathrm{C}$. Spikes from plants were used for DNA extraction. Initially, spikes were cut apart with sterilized scissors and washed in distilled water and ethanol $(70 \%)$ and dried on fresh tissue paper to remove spore of microorganisms and any other source of foreign DNA. The collected spike samples were then kept in polythene bags and for avoiding any damage of the tissues, the bags were placed in an icebox and brought out to the laboratory where the samples were stored in $-80{ }^{\circ} \mathrm{C}$ freezer.

\subsection{Sample Analysis}

The collected samples were analyzed for the presence of MoT following both conventional pathological techniques and molecular techniques.

In conventional techniques, moist chamber and agar plate methods were employed.

a) Inocula Preparation

Collected samples of wheat spikes were cut into small parts of 2-3 cm long. For the moist chamber, inocula were directly placed on moist blotter. For PDA plates, inocula were surface sterilized with $10 \%$ Clorox for 1 min, rewashed the inocula three times in sterile water.

b) Moist Chamber Incubation

Moist chambers were prepared in plastic Petri dishes $(9 \mathrm{~cm}) .1-2$ filter papers/blotter soaked in sterile water were placed in the Petri dishes. 3-4 inocula were placed on the moist blotter in equal distance and incubated at room temperature $\left(25 \pm 1^{\circ} \mathrm{C}\right)$. Observations were made for the growth of MoT out of the inocula.

c) Preparation of Water Agar Medium

In the experimental studies, the standard water agar medium was used. Tape water was boiled for 15-20 minutes. Then agar ( $20 \mathrm{~g}$ ) was dissolved in the water and the volume was made up to $1000 \mathrm{ml}$ by adding distilled water and $2 \mathrm{ml}$ lactic acid was added to it to avoid bacterial contamination. A known quantity of medium was poured into number of conical flasks. The flasks were plugged with nonabsorbent cotton and finally wrapped with brown paper. The flasks containing dispensed medium was sterilized at $121{ }^{\circ} \mathrm{C}$ with 15 PSI pressure for about 30 minutes (Samson et al., 2015).

\section{d) Preparation of Oat Meal Agar (OMA) Medium}

Fifty grams oat were boiled in $600 \mathrm{ml}$ distilled water for 1 hour and the extract was collected by filtering through a muslin cloth. Agar $(15 \mathrm{~g})$ was dissolved in the oat extract in a conical flask and the volume was made up to 1000 $\mathrm{ml}$ by adding distilled water. The flask containing the medium was sterilized at $121{ }^{\circ} \mathrm{C}$ with 15 PSI pressure for about 30 minutes (Siddique, 2014). Then 4-5 tea spoon of Streptophen was added in the flask. Finally, the prepared medium was stored in refrigerator with proper labeling. Later the medium was melted and poured in sterile glass petri-dishes.

e) Purification and Multiplication of the Pathogens

Mycelia of the fungi were transferred from spikelet surface and infected parts of the sample to OMA medium with the help of sterile pointed needle. Then, tip of the fungal colony was transferred to PDA plates and incubated at $25{ }^{\circ} \mathrm{C}$ temperature with more than $80 \%$ relative humidity for luxuriant growth. Thus, the pure cultures of the pathogen were obtained. Then necessary multiplication of the pathogen was done.

f) Maintenance of Magnaporthe Oryzae Triticum Pathogen

The pure culture was obtained by transferring young immature whitish mycelia from culture plate to a fresh PDA slant and incubated for 10-15 days. From this culture, a young whitish mycelium was again transferred to sterilized PDA slant. Thus a pure culture was obtained and maintained by sub culturing (Figure 1). In molecular techniques conventional PCR methods were employed. 


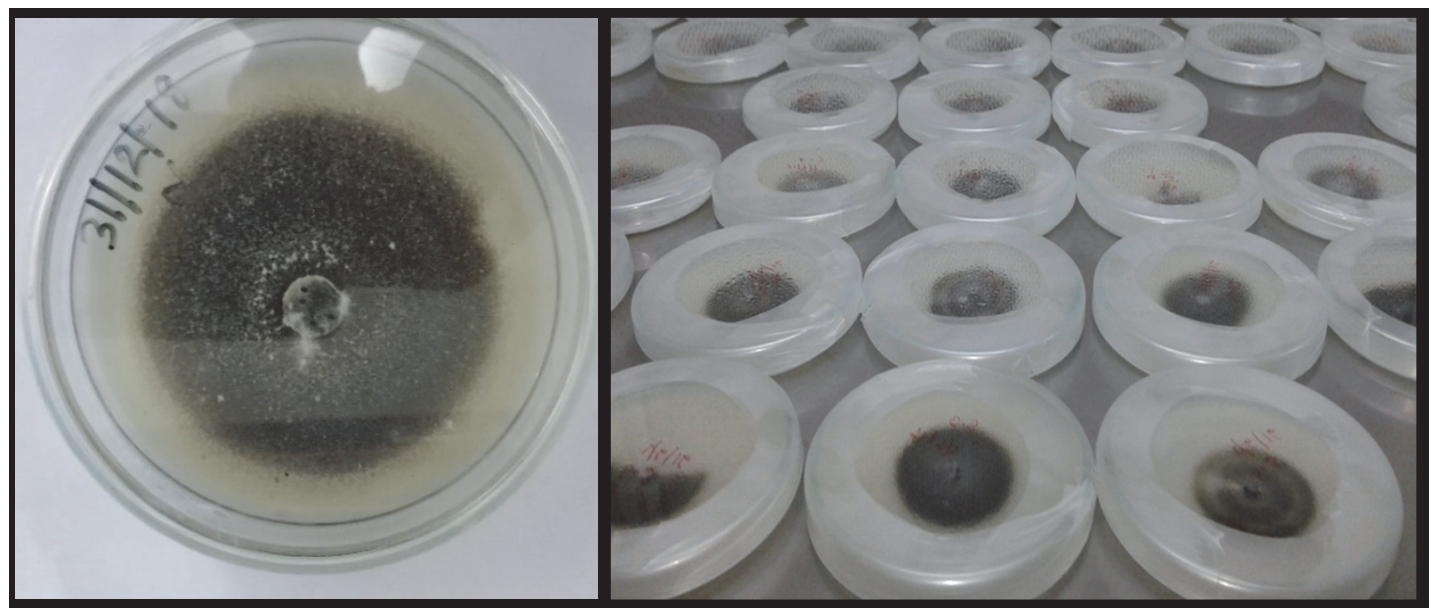

Figure 1. Pure culture of Magnaporthe oryzae triticum

\section{a) DNA Extraction of Wheat Spikes}

A modified mini-prep DNA extraction method developed by Edwards et al. (1991) was followed in this experiment. The simplified mini scale procedure for DNA isolation in PCR analysis of this method was done in the Biotechnology Lab, BINA. The quality of the isolated DNA in the protocol was sufficient for PCR analysis. One set of $2 \mathrm{~mL}$ microfuge tubes were labeled with the sample names for harvesting tissue, and the second set of 1.5 $\mathrm{mL}$ tubes were labeled for the DNA extraction with the same sample names. It is most efficient to work in sets of 24 tubes at a time. The samples were brought to the DNA extraction lab, the water bath was fixed to $65^{\circ} \mathrm{C}$, water level checked, and the extraction buffer was pre-heated before use (30 sec in the microwave). The spike samples were cut into $2-3 \mathrm{~cm}$ pieces and the sample was crushed in small mortar and pestle. After crushing, the tubes were removed to a room temperature tube rack, to let them warm up briefly (2-3 min.) then $800 \mu 1$ re-heated extraction buffer was added and mixed well by vortexing and inverting. The tubes were placed in a $65^{\circ} \mathrm{C}$ water bath in a tube holder for 20 minutes (after 10 minutes mixed by inverting and return to the water bath). The tubes were removed, mixed by inverting, and brought to a chemical fume hood. Then $800 \mu \mathrm{L}$ chloroform mix was added (24:1 mixture of chloroform and isoamyl alcohol). Tubes were closed tightly, placed in tube rack, covered with paper towels and hold a second tube rack against the top of the tubes and inverted repeatedly for 3 minutes. The tubes were centrifuged for 8 minutes at 11,000 rpm in a micro centrifuge. $500 \mu \mathrm{l}$ of the upper aqueous layer was removed to a new $1.5 \mathrm{~mL}$ tube (already labeled) being careful not to pipette near the "dirty" layer. Later, the chloroform and plant tissue were poured into a liquid organic waste container. $1000 \mu \mathrm{l}$ of cold $100 \%$ ethanol was added and mixed by inverting. Then Centrifuged for 12 minutes at maximum speed (13,200 rpm). A small pellet was visible. The solution was decanted by pouring the solution into a beaker and then touched the tip of the tube to a tissue to remove the excess solution (or pipette off excess solution with a P 200). $1000 \mu \mathrm{l}$ cold $70 \%$ ethanol was added to all tubes (adding at an angle away from the side of the tube with the DNA pellet) and spinned for 3 minutes at 13,200 rpm. The pellet was dried by inverting the tubes on a bench top on top of tissue for 30-45 min. It was made sure that there is no residual ethanol, but also not dried too long (which makes re-suspending difficult). The pellet was re-suspended in $100 \mu \mathrm{TE}$ buffer and dissolved pellet by warming in a $65^{\circ} \mathrm{C}$ water bath for up to $1 \mathrm{hr}$ (with frequent mixing or flicking the tube with finger). After the pellet was dissolved, the concentrated DNA was stored at $-20^{\circ} \mathrm{C}$.

\section{b) Conventional PCR}

The PCR cocktail including DNA had a total volume of $10 \mu \mathrm{l} /$ reaction based on a wheat protocol (Pieck et al., 2013) was placed in the PCR tubes and run in the DNA thermal cycler. For a single reaction $3.5 \mu \mathrm{L}$ of Green taq polymerase, $0.5 \mu \mathrm{L}$ of dNTPs, $0.25 \mu \mathrm{L}$ of DNA Polymerase, $1 \mu \mathrm{L}$ of Primer (forward+reverse) and $3.75 \mu \mathrm{L}$ of $\mathrm{ddH}_{2} \mathrm{O}$ was required. For 15 reactions, at first $3.75 \mu \mathrm{l}$ of sterilized ddH2O, $2.5 \mu \mathrm{l}$ of DNA polymerase, $0.5 \mu \mathrm{l}$ of dNTPs were taken in a $1.5 \mathrm{ml}$ PCR tube. Then $1 \mu \mathrm{l}$ of primer (forward and reverse) were added. The mixture was then vortexed. At last $3.5 \mu \mathrm{l}$ of Taq DNA polymerase was mixed with it. $1.0 \mu \mathrm{l}$ of each template DNA samples were pipette into the wells of the PCR tubes for PCR amplification with initial denaturation at $94^{\circ} \mathrm{C}$ for $90 \mathrm{~s}$; followed by 30 cycles of $94^{\circ} \mathrm{C}$ for $30 \mathrm{~s}, 62^{\circ} \mathrm{C}$ for $30 \mathrm{~s}$, and $72^{\circ} \mathrm{C}$ for $60 \mathrm{~s}$; and a final extension at $72^{\circ} \mathrm{C}$ for $2 \mathrm{~min}$. Amplified PCR products were analyzed on $2 \%$ agarose gels and stained with ethi-dium bromide. About $2 \mu 1$ of 
each PCR product was loaded in each well. DNA size marker like 100 bp DNA ladder was used for size determination. After staining, the gel was taken out carefully from the staining tray and placed on high performance ultraviolet light box (UV-trans-illuminator) of GEL Doc for checking the DNA bands.

Table 1. The sequence and size of the selected specific primer used in this study

\begin{tabular}{|c|c|c|c|c|c|}
\hline $\begin{array}{l}\text { Primer } \\
\text { Name }\end{array}$ & Seqa & Sequence & & $\begin{array}{l}\text { Annealing } \\
\text { temperature }\left({ }^{\circ} \mathrm{C}\right)\end{array}$ & Target species \\
\hline \multirow[t]{2}{*}{ MoT1 } & \multirow[t]{2}{*}{ WB01 } & Forward & GCTGTTCTGGGCCACCTAC & \multirow[t]{2}{*}{62} & \multirow{2}{*}{$\begin{array}{l}\text { Magnaporthe } \\
\text { oryzae triticum }\end{array}$} \\
\hline & & Reverse & ATTCCTCCCCGATTTCCTTT & & \\
\hline
\end{tabular}

\section{c) Statistical Analysis}

The collected data were analyzed statistically by using Web Agri Stat Package (WASP) program, version 2 software. The mean of all the treatments was compared by Tukey's HSD test with a 95\% level of significance.

\section{Results and Discussion}

\subsection{Symptoms of Wheat Blast}

The infection appeared on the emerging heads at pre-heading stage generally at 46-49 days age of wheat plants. The infection appeared as whitening of the spike most commonly from the top. Infection occurred on the emerging head in different points i.e. in the middle or near the tip or at the base (Figure 2). The common thing was observed that irrespective of the point of infection, whitening commonly called bleaching from the top downward. It means if infection occurred at the base, the whole of the spike bleached, infection near the top caused bleaching of the spike from top to down the point of infection and an infection in the middle caused bleaching of the half of the spike from the top. However, with time the whole of the spike in all cases turned silvery-white i.e. completely bleached.

\subsection{Isolation and Characterization of Magnaporthe Oryzae Triticum}

Infected spikes were collected, room dried and stored at $4{ }^{\circ} \mathrm{C}$ in brown paper envelopes. Microscopic slides were prepared through picking up fungal structures from the infected spikelets and observed under microscope. Secondly, infected spikelets were observed directly under stereo binocular microscope and recorded the fungal structures on the surface of the grains and prepared slides picking up those structures with needles. Thirdly, infected spikelets were splitted into small parts and incubated in moist chamber and agar plates. The plates were observed for fungal growth. Slides were prepared picking up growing fungal structures and observed under a microscope. Pyriform 3 celled hyaline conidia with beaks of different length were observed in plenty (Figure 2).

\subsection{Germination of Mot Spores}

Continued observation of the watch glass under microscope revealed MoT started germination producing germ tube within $12 \mathrm{~h}$. Germ tubes were seen developed from both ends as well as from side cells (Figure 2). The germination of the spores confirmed that the infected samples collected from wheat plants of the experimental plot were in live condition.

\section{Screening M1 population}

M1 population in the BINA campus did not find any infection of Magnaporthe oryzae triticum.

\section{Screening M2 population}

The experiment in farmers field found infection of Magnaporthe oryzae triticum showing different levels of disease incidence (DI) and disease severity (DS). Both DI and DS increased with time. At the initial stage infection of Magnaporthe oryzae triticum was low which showed a very alarming hike towards the end of the season.

\subsection{Effect of Seed Irradiation on The Incidence and Severity of Blast of Wheat Under Natural Infection}

Seed irradiation at different doses significantly affected the incidence of blast disease of three wheat varieties infected at the pre-heading stage (Table 2). 


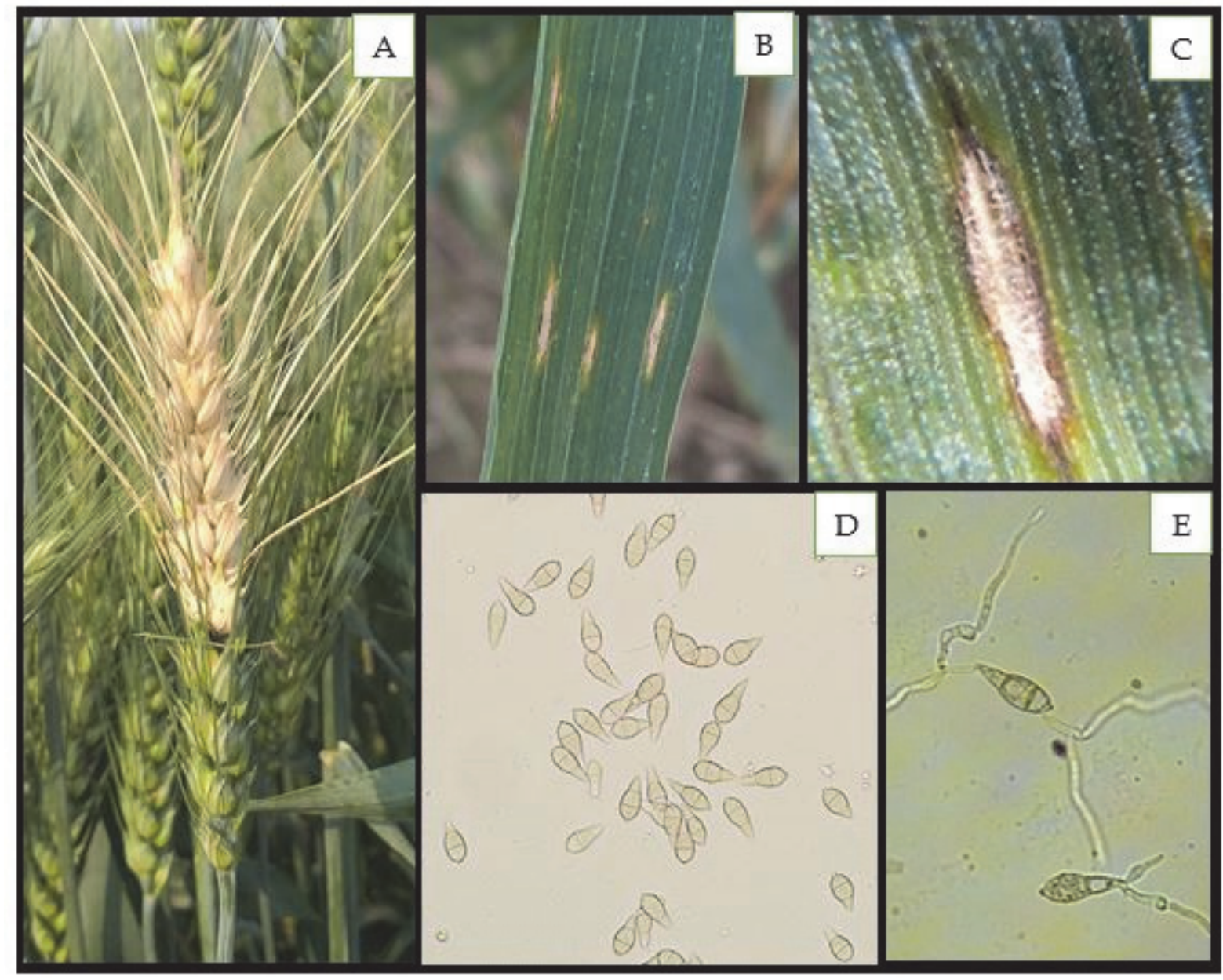

Figure 2. A. Typical blast symptoms of bleaching of spikes B. Symptoms on leaf (eye shaped spot) C. Lesion photo taken by mobile microscope (60X view) D. Microscopic view of MoT spores (40X view) C. Germinating spores

Table 2. Effect of seed irradiation on the incidence and severity of blast of wheat on three wheat varieties under natural infection

\begin{tabular}{ccccccc}
\hline \multirow{2}{*}{ Irradiation } & \multicolumn{2}{c}{ BARI Gom-25 } & \multicolumn{2}{c}{ BARI Gom-29 } & \multicolumn{2}{c}{ BARI Gom-30 } \\
\cline { 2 - 7 } & $\begin{array}{c}\text { Disease } \\
\text { Incidence } \\
(\%)\end{array}$ & $\begin{array}{c}\text { Disease } \\
\text { Severity } \\
(\%)\end{array}$ & $\begin{array}{c}\text { Disease } \\
\text { Incidence } \\
(\%)\end{array}$ & $\begin{array}{c}\text { Disease } \\
\text { Severity } \\
(\%)\end{array}$ & $\begin{array}{c}\text { Disease } \\
\text { Incidence } \\
(\%)\end{array}$ & $\begin{array}{c}\text { Disease } \\
\text { Severity } \\
(\%)\end{array}$ \\
\hline No Irradiation & $56.66 \mathrm{a}$ & $87.33 \mathrm{a}$ & $48.00 \mathrm{a}$ & $94.00 \mathrm{a}$ & $34.33 \mathrm{a}$ & $85.00 \mathrm{a}$ \\
$150 \mathrm{~Gy}$ & $37.33 \mathrm{c}$ & $80.00 \mathrm{~b}$ & $30.00 \mathrm{c}$ & $81.66 \mathrm{~b}$ & $29.33 \mathrm{~b}$ & $74.33 \mathrm{~b}$ \\
$200 \mathrm{~Gy}$ & $22.33 \mathrm{~d}$ & $42.33 \mathrm{~d}$ & $28.66 \mathrm{c}$ & $72.66 \mathrm{~b}$ & $18.00 \mathrm{c}$ & $51.66 \mathrm{e}$ \\
$250 \mathrm{~Gy}$ & $32.33 \mathrm{c}$ & $52.33 \mathrm{c}$ & $17.33 \mathrm{~d}$ & $60.00 \mathrm{c}$ & $25.00 \mathrm{~b}$ & $57.66 \mathrm{~d}$ \\
$300 \mathrm{~Gy}$ & $44.00 \mathrm{~b}$ & $75.00 \mathrm{~b}$ & $36.00 \mathrm{~b}$ & $77.66 \mathrm{~b}$ & $28.66 \mathrm{~b}$ & $68.33 \mathrm{c}$ \\
\hline
\end{tabular}

The letters denote statistical differences at the $95 \%$ level using Tukey's HSD (honestly significant difference) test.

Seed irradiation caused a notable impact on the incidence and severity of blast on wheat varieties. Variation in the doses posed a significant difference on both incidence and severity. In all the varieties, wheat plants from nonradiated seeds carried the maximum wheat blast infection. Within the varieties, difference in radiation doses caused significant variation in blast infection (Table 2). Among the treatments, 200 Gy and 250 Gy reduced the disease effectively. The maximum disease incidence (56.66\%) was found in control of BARI Gom-25 and the maximum 
disease severity $(94.00 \%)$ was found in control of BARI Gom-29. The minimum disease incidence $(17.33 \%)$ was found in $250 \mathrm{~Gy}$ treated seed of BARI Gom-29 and the minimum disease severity $(42.33 \%)$ was found in 200 Gy treated seed of BARI Gom-25. In case of BARI Gom-25 and BARI Gom-30, the performance of 200 Gy was mentionable for their ability to suppress disease incidence and severity.

\subsection{Quantification of DNA}

The DNA isolated from infected spikes of M2 families of wheat was quantified through NanoDrop ${ }^{\mathrm{TM}}$

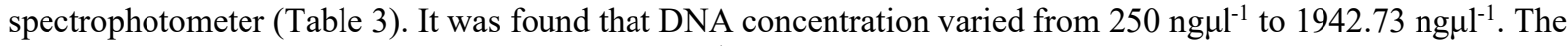

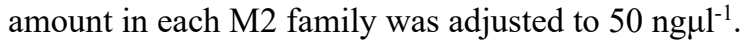

Table 3. The concentration of DNA of $15 \mathrm{M} 2$ families of wheat spike sample

\begin{tabular}{lllll}
\hline Sl. No. & \multirow{2}{*}{ Treatments } & $\begin{array}{l}\text { DNA Concentration } \\
1\end{array}$ & $\begin{array}{l}\text { ng }^{-} \\
\text {Absorbance Ratio } \\
\text { A260/280 }\end{array}$ & A260/230 \\
\hline 1. & BWM-1 & 583.80 & 1.41 & 0.82 \\
2. & BWM-2 & 250.08 & 1.34 & 0.78 \\
3. & BWM-3 & 647.10 & 1.86 & 0.60 \\
4. & BWM-4 & 299.64 & 1.60 & 0.57 \\
5. & BWM-5 & 616.24 & 1.70 & 0.52 \\
6. & BWM-6 & 266.02 & 1.97 & 0.78 \\
7. & BWM-7 & 481.57 & 1.92 & 1.57 \\
8. & BWM-8 & 417.83 & 2.05 & 1.37 \\
9. & BWM-9 & 347.89 & 2.02 & 1.77 \\
10. & BWM-10 & 388.13 & 1.16. & 1.64 \\
11. & BWM-11 & 288.89 & 1.83 & 0.64 \\
12. & BWM-12 & 272.60 & 2.00 & 0.93 \\
13. & BWM-13 & 1942.73 & 1.54 & 0.84 \\
14. & BWM-14 & 1062.43 & 2.01 & 0.69 \\
15. & BWM-15 & 386.48 & 2.02 & 1.47 \\
\hline
\end{tabular}

BWM-1: BARI Gom-25 (150Gy), BWM-2: BARI Gom-25 (200Gy), BWM-3: BARI Gom-25 (250Gy), BWM-4: BARI Gom-25 (300Gy), BWM-5: BARI Gom-25 (Control), BWM-6: BARI Gom-29 (150Gy), BWM-7: BARI Gom-29 (200Gy), BWM-8: BARI Gom-29 (250Gy), BWM-9: BARI Gom-29 (300Gy), BWM-10: BARI Gom29 (Control), BWM-11: BARI Gom-30 (150Gy), BWM-12: BARI Gom-30 (200Gy), BWM-13: BARI Gom-30 (250Gy), BWM-14: BARI Gom-30 (300Gy), BWM-15: BARI Gom-30 (Control)

\subsection{PCR Based Detection of Magnaporthe Oryzae Triticum Using Specific Primer}

Genomic DNA was extracted from 15 infected M2 wheat spike samples. The DNA concentration was found

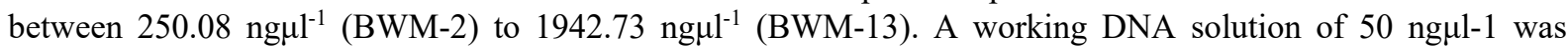
prepared for each sample. Polymerase Chain Reaction (PCR) of the extracted genomic DNA from the infected samples was done using MoT1 primer. The results showed that nine M2 families' samples (BWM-2, BWM-4, BWM-5, BWM-8, BWM-10, BWM-11, BWM-13, BWM-14, and BWM-15) clearly amplified an amplicon of 350 bp by MoT1 primer. (Figure 3). The other seven M2 families did not show any amplification by this primer. 


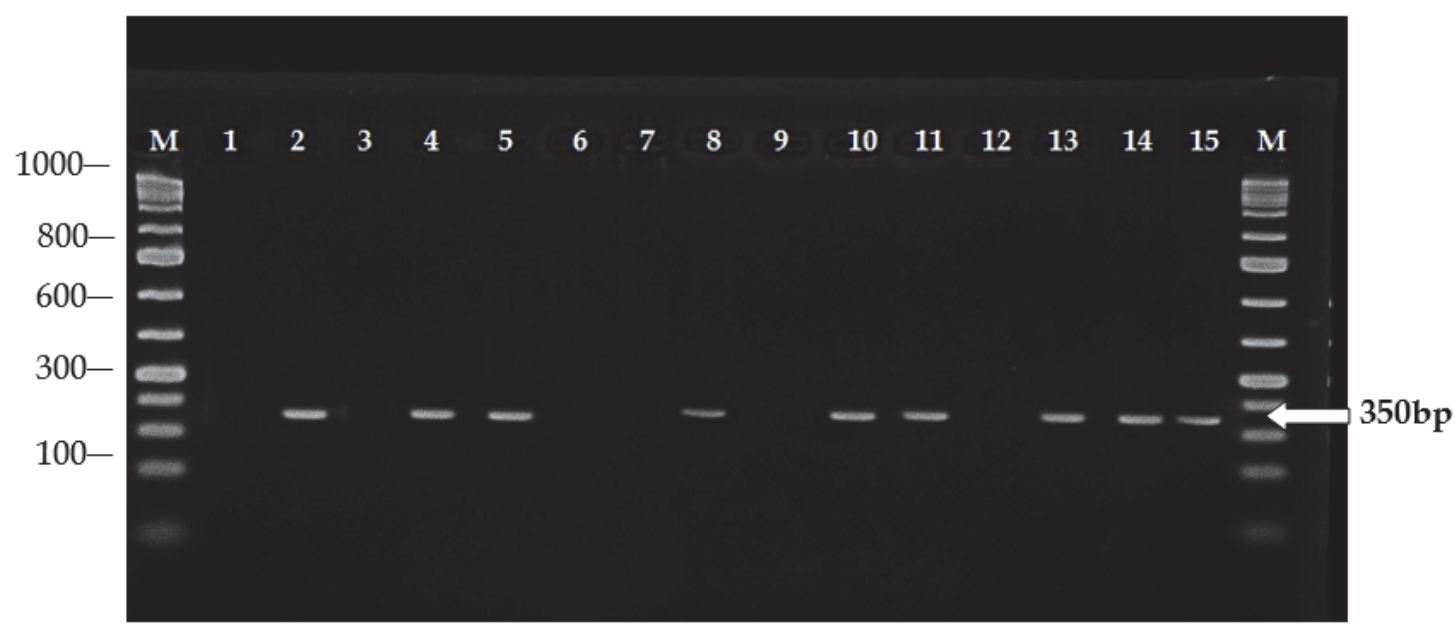

Figure 3. Agarose gel electrophoresis of DNA of wheat blast infected spikes of M2 families amplified with primer MoT1. Lane M-100bp DNA ladder; Lane (1-15) contains PCR products of 15 M2 families (BWM-1 to BWM-15). An amplicon size of $350 \mathrm{bp}$ found in spikes of nine M2 families. The size of the band confirms the infection of M2 families by MoT

In general, disease incidence and severity on the M2 plants were reflected on the presence or absence of banding on agarose gel except in few cases. The MoT infection was recorded on all the M2 families while molecular detection of disease by MoT1 primer was found in nine M2 families. The primer detected the expression of the disease as an amplicon of $350 \mathrm{bp}$ semi-quantitatively. It showed that semi-quantitative detection of disease which varied in different M2 families of wheat. The low infection might not be detected by MoT1 primer only. Therefore, further analysis should be done using other specific primers like MoT2, MoT3, etc. For the quantitative expression of Magnaporthe oryzae triticaum, Real Time PCR study is recommended.

The research findings of the present investigation have some similarities to the findings of Vishwakarma et al., 2017 who mutagenized by gamma rays a high yielding wheat variety, DBW-88 (released in 2014) at different doses (viz.200, 250, 300 \& 350 Gy), raised M2 generation in Kernel, Indian Institute of Wheat and Barley Research (IIWBR), a hot spot for yellow rust. Variable resistance compared to susceptible parent was observed. Continued selection until M5 generation yielded immune mutant wheat against the susceptible parent variety (6080S) (Vishwakarma et al., 2017).

Similarly, in 2004, Wonchu mutant variety of Oryza sativa was developed by irradiating seeds at 250 Gy of gamma rays. This variety has been shown to have higher yield and better disease resistance (Raina and Danish, 2018).

\section{Conclusion and Recommendations}

Radiation doses of 200 Gy and 250 Gy performed better in suppressing wheat blast incidence and severity and among the evaluated variety BARI Gom-30 performed best followed by BARI Gom-25 and BARI Gom-29. These mutant lines need to be advanced to M3 through M5 and artificially inoculated with wheat blast pathogen and evaluated for resistance. The findings of the present study enhance the way of more investigation on wheat blast disease resistant line screening. Irradiated seeds are not harmful to the ecosystem rather completely safe for human health. Therefore, irradiation can be utilized as an alternative approach for combating with wheat blast by developing resistant variety which will reduce the use of chemical pesticides as well as farmers additional cost to purchase pesticides.

\section{Acknowledgments}

The authors would like to express their thanks to KGF, Bangladesh for fund support to conduct this research. They are grateful to BINA authority, Bangladesh for providing the field and laboratory facilities. Also we extend our thanks to the farmers at Mahepur, Bangladesh who helped us during our study. The authors declare no conflicts of interest regarding this manuscript.

\section{References}

Ahmed, S., Alam, M. J., Awan, T. H., \& Islam, AKMM. (2019). Herbicidal weed control in drill sown spring wheat under Bangladesh condition. Fundamental and Applied Agriculture, 4(2), 839-848. 
https://doi.org/10.5455/faa.34774

Banglapedia. (2014). National Encyclopedia of Bangladesh. Retrieved from http://en.banglapedia.org/in dex.php?title=Wheat

BINA. (2018). Annual report of Bangladesh Institute of Nuclear Agriculture (2017-2018).

CIMMYT. (2017). Understanding and managing the threat of wheat blast in South Asia, South America, and beyond. Retrieved from https://repository.cimmyt.org/xmlui/ha ndle/10883/16947

Cruz, C. D., Peterson, G. L., Bockus, W. W., Kankanala, P., Dubcovsky, J., Jordan, K.W., Akhunov, E., Chumley, F., Baldelomar, F. D., \& Valent, B. (2016). The 2NS translocation from Aegilops ventricosa confers resistance to the Triticum pathotype of Magnaporthe oryzae. Crop Science Society of America, 56(3), 990-1000. https://doi.org/10.2135/cropsci2015.07.0410

FAO Report. (2016). The Food and Agriculture Organization of the United Nations Rome, Italy. www.fao.org/.../2016/160801_BGDSurveyCalendar_Expectations_fromAgCensus

FAO/IAEA. (2018). Manual on Mutation Breeding Third edition. Spencer-Lopes MM, Forster BP and Jankuloski L. Food and Agriculture Organization of the United Nations, Rome, Italy. pp 301. Retrieved from http://www.fao.org/3/I9285EN/i9285en.pdf

Goulart, A.C.P., Sousa, P.G. and Urashima, A.S. (2007). Damages in wheat caused by infection of Pyricularia grisea. Summa Phytopathologica, (33), 358-363. http://doi.org/10.1590/1808-1657000952017

IAEA. (2017). Mutant variety database of International Atomic Energy Agency. Retrieved from https:// mvd.iaea.org/\#!Variety/4465

Igarashi, S. (1991). Update on wheat blast (Pyricularia oryzae) in Brazil. In: Proceedings of the international conference on wheat for the nontraditional warm areas. Foz do Iguaçu, Brazil. (Saunders D eds.). Mexico DF, Mexico. CIMMYT. (3), 480-483.

Kato, H. (1994). Phylogenetic aspects of Magnaporthe grisea on cereals-Origin and dissemination. Annals of the Phytopathological Society of Japan, (60), 266-268.

Khursheed, S., Raina, A., Parveen, K., \& Khan, S. (2017). Induced phenotypic diversity in the mutagenized populations of faba bean using physical and chemical mutagenesis. Journal of the Saudi Society of Agricultural Sciences. http://doi.org/10.1016/j.jssas.2017.03.001

Kohli, M. M., Mehta, Y. R., Guzman, E., De Viedma, L., \& Cubilla, L. E. (2011). Pyricularia blast a threat to wheat cultivation. Journal of Genetics and Plant Breeding, (47), 130-134. http://doi.org/10.17221/3267CJGPB

Malaker, P. K., Barma, N. C. D., Tiwari, T. P., Collis, W. J., Duveiller, E., Singh, P. K., \& Joshi, A. K. (2016). First Report of Wheat Blast Caused by Magnaporthe Oryzae Pathotype Triticum in Bangladesh. Plant Disease. 100(11), 2330-2330. https://doi.org/10.1094/PDIS-05-16-0666-PDN

Meah, M. B., Salam Moin, U., Khan, A. A., \& Kabir, W. (2016). Wheat Blast in South Western Region of Bangladesh. Report submitted to FAO (BD) on the survey of wheat blast incidence in March 2016. Survey period 14-20 March 2016. Pp 7.

Monsur, M. A., Ahmed, M., Haque, A., Jahan, Q. S. A., Ansari, T. H., Latif, M. A., Borma, N. C. D., Ali, M. A., Kabir, M. S., \& Banik, B. R. (2016). Research update of cross infection between rice and wheat blast at BRRI. Presented on 27 October Bangladesh Agricultural Research Council (BARC), Dhaka, Bangladesh.

Özge, Ç., \& Çimen, A. (2017). Applications of Ionizing Radiation in Mutation Breeding, New Insights on Gamma Rays, Ahmed M. Maghraby, Intech Open. Retrieved from https://www.intechopen.com /books/new-insightson-gammarays/applications-of-ionizing-radiation-in-mutation-breeding

Pieck, M. L., Ruck, A., Farman, M. L., Peterson, G. L., Stack, J. P., \& Valent, B. (2016). Genomics-based marker discovery and diagnostic assay development for wheat blast. Plant Disease, (101), 103-109. https://doi.org/10.1094/PDIS-04-16-0500-RE.

Raina, A., \& Danish, M. (2018). Mutagenesis in Plant Breeding for Disease and Pathogen Resistance. Agricultural Research \& Technology, 13(1), 1-2. https://doi.org/10.19080/ARTOAJ.2018.13.555869

Raina, A., Laskar, R. A., Khursheed, S., Amin, R., \& Tantray, Y. R. (2016). Role of mutation breeding in crop improvement-past, present and future. Asian Research Journal of Agriculture, (2), 1-13. https://doi.org/10.9734/ARJA/2016/29334 
Raina, A., Laskar, R. A., Khursheed, S., Khan, S., \& Parveen, K. (2017). Induce Physical and Chemical Mutagenesis for Improvement of Yield Attributing Traits and their Correlation Analysis in Chickpea. International Letters of Natural $\quad$ Sciences, $\quad$ (61), https://doi.org/10.18052/www.scipress.com/ILNS.61.14

Samson, R. A., Hoekstra, E. S., Lund, F., Filtenborg, O., \& Frisvad, J. C. (2015). Methods for the Detection, Isolation and Characterization of Food-borne Fungi, Central bureau voor Schimmelcultures, Utrecht, The Netherlands and BioCentrum DTU, Technical University of Denmark, DK-2800 Lyngby, Denmark.

Siddique, S., Syed, Q., Adnan, A., Nadeem, M., Irfan, M., \& Ashraf, Q. F. (2014). Production of Avermectin B1b from Streptomyces avermitilis 41445 by Batch Submerged Fermentation. Jundishapur J. Microbiology, 6(8). https://doi.org/10.5812/jjm.7198

Singh, R. P., Singh, P. K., Rutkoski, J., Hodson, D. P., He, X., \& Jørgensen, L. N. (2016). Disease impact on wheat yield potential and prospects of genetic control. Annual Review of Phytopathology, (54), $303-322$. https://doi.org/10.1146/annurev-phyto-080615-095835

Singh, S. M., Bhardwaj, S. C., Chatrath, R., Sharma, P., Chaudhary, A. K., \& Gupta, R. K. (2016). Wheat Blast Disease- An Overview. Journal of Wheat Research, 8(1), 1-5.

Urashima, A. S., Bockus, W. W., Bowden, R. L., Hunger, R. M., Morrill, W. L., Murray, T. D., \& Smiley, R. W. (2010). Compendium of wheat diseases and pests (3rd Ed). American Phytopathological Society, 22-23.

Vishwakarma, G., Das, B. K., Kumar, S., Mishra, C. N., Saharan, M. S., \& Saini, A. (2017). Radiation Induced Mutations for Developing Enhanced Resistance to Yellow (stripe) Rust of Wheat. BARC Newsletter NovDec/17.

\section{Copyrights}

Copyright for this article is retained by the author(s), with first publication rights granted to the journal.

This is an open-access article distributed under the terms and conditions of the Creative Commons Attribution license (http://creativecommons.org/licenses/by/4.0/). 